website:http://jsci.utq.edu.iq

Email: utjsci@utq.edu.iq

\title{
Molecular diagnosis of visceral leishmaniasis in children of Basrah governorate, Iraq
}

\author{
Maha K. AL-Mishry \\ Maane N. Al-Shimmary \\ Nazim K.Mahdi* \\ College of Medicine- Al-Qadisiya University \\ * College of Medicine- Basrah University
}

\begin{abstract}
$\underline{\text { Abstract }}$
The laboratory diagnosis of visceral leishmaniasis is based on microscopic examination, culture, serological tests and molecular methods. This study include 50 cases of suspected Visceral Leishmaniasis (VL) patients in 3 hospitals (Al-Basrah Maternity and Children, Al-Basrah General and Al-Tahreer) during the period from December 2011 to July 2012, and 25 healthy child from health care centers in Basrah. We examined their Bone Marrow aspirates by microscopic examination and DNA amplification from peripheral blood by Polymer Chain Reaction (PCR) technique .We calculated positive- negative predictive values and the sensitivity-specificity of these diagnosis tests. Positive predictive value of microscopic examination were $45(90 \%)$ and (10\%) negative for visceral leishmaniasis and for PCR 42(84\%) positive, 8 (16\%) negative ,the sensitivity and specificity for PCR $93.3 \%$ and $100 \%$ respectively, with statistically significant different $(\mathrm{p}<0.01)$.
\end{abstract}

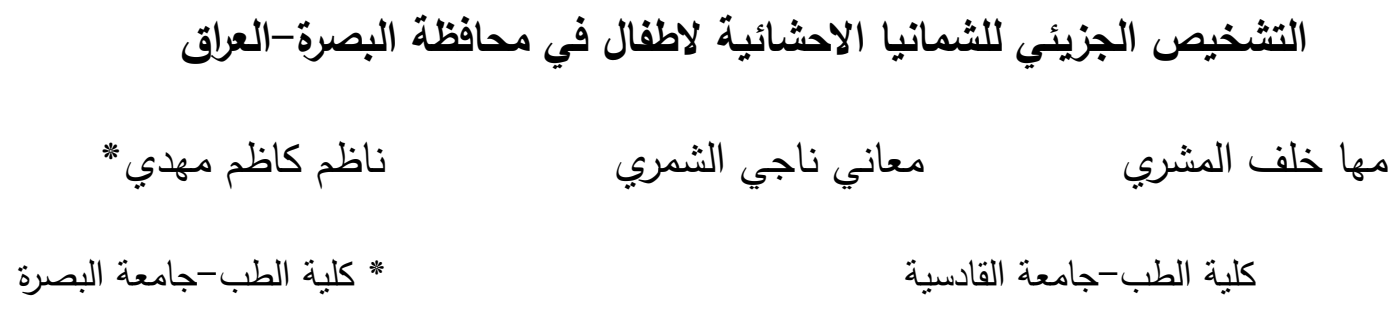

المستخاصن

اجريت هذة الدراسة في تثخيص مرض اللثمانيا الحشوية للاطفال في محافظة البصرة باستخدام طريقة الاختبار الجزيئي( التفاعل السلسلي لانزيم البلمرة) حيث تعتبر من الطرق الحديثة في التشخيص المختبري.

تضمنت هذة الدراسة 50 حالة من الاطفال المشتبة باصابتهم باللثمانيا الحشوية والذين احيلوا الى ردهات الاطفال في مستشفى البصرة العام

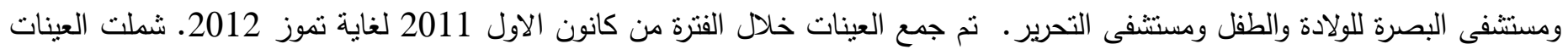

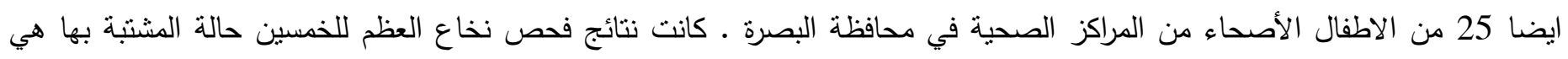

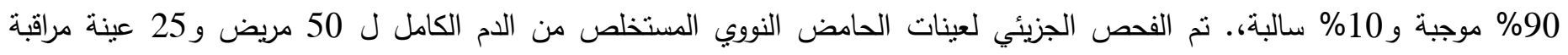

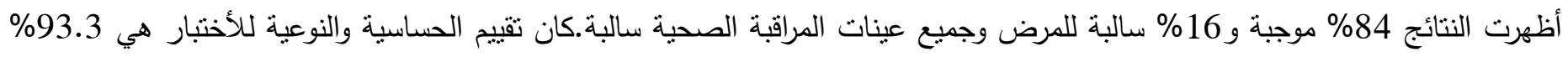

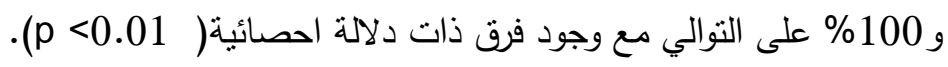




\section{Introduction}

Leishmaniasis is the result of parasitic infection with a protozoan flagellate of the family Trypanosomatidae, order Kinetoplastida. The genus is Leishmania. This Leishmania are obligatory parasites that alternate between the invertebrate vector (the sand fly) and a vertebrate host, which may be human, canine, rodent or other. The female sand fly acquires the infection while taking a blood meal from the vertebrate host (Claborn 2010). At least 23 species of Leishmania cause human disease, and most occur in the tropics and subtropics of both the Old and New Worlds. Human disease is usually described as occurring in three primary manifestations: cutaneous, mucocutaneous and visceral. Leishmaniasis is probably second only to malaria in importance as a protozoan disease causing human suffering (Lawyer and Perkins 2004). . Fatalities due to leishmaniasis are associated with visceral disease, through fevers, malaise and weight loss associated with anemia, hepatomegaly and splenomegaly. Secondary bacterial infections leading to tuberculosis, pneumonia and diarrhea contribute to high mortality in untreated disease (Wilson 1998). Leishmaniasis can be found in 88 countries. Visceral leishmaniasis (VL) is endemic in 62 countries. The World Health Organization reports (WHO 1990, 1995) an annual incidence of 600,000 cases but estimates up to 1.5 million new cases of cutaneous leishmaniasis and 500,000 cases of visceral leishmaniasis occur each year. Clinical features of VL can be easily mistaken for other febrile illnesses such as malaria and enteric fever. Early case detection followed by adequate treatment is central to the control of VL. most of the antileishmanial drugs are toxic. so, such tests should be highly sensitive and specific (Deborggraeve et al., 2008).

Parasitological diagnosis by detection of parasite in clinical material remains the gold standard in the diagnosis of leishmaniasis because of its high specificity (Herwaldt 1999). Bone marrow and the lymph node smears have lower sensitivity ranging from 52-85\% and 52- 58\% respectively, Bone marrow aspiration (BMA) or splenic aspirations are painful and risky techniques (Srivastava et al., 2011a).PCR-based assays offer an alternative method to the detection of parasites in clinical samples. Variety of sensitivities and specificities of various PCR based diagnostic assays targeting different regions of leishmania genome has been reported (Srivastava et al., 2011a) PCR-based assays of molecular diagnosis with primers targeting several multicopy genes,e.g., rRNA genes, kinetoplast DNA (kDNA) minicircles.(Attar et al.,2001)

The objective of this study was to evaluate the efficacy of PCR technique with peripheral blood samples in diagnosing pediatrics VL, comparing with the most commonly method that uses the invasive collection of sample and direct microscopy of bone marrow aspirates smear.

\section{Materials and Methods}

This study was carried out for 6 months (from the first of December 2011 till the end of June 2012), There were two groups of children (patients and apparently healthy children) ,Patients group included children that were admitted to pediatric wards of Basra maternity and children hospital, Basra general hospital and AL-Tahreer hospital. 50 Children with a clinical sign suspected of visceral leishmaniasis. 50 suspected patients smear slides were prepared from bone marrow aspirates, fixed with ethanol, stained with Giemsa and analyzed by specialists experienced in VL diagnosis. Healthy children group (negative control) included 25 apparently healthy children that had visited primary health care center in Basra governorate for vaccination. Blood sample $(2-3 \mathrm{ml})$ of blood was collected in sterilized tubes with EDTA for DNA extraction. The prepared culture for parasite Leishmania donovani was obtained from leishman center follow to AL-Nahren University (Moham/IQ/2005/MRCIO) was used as positive control. Detached cell from the flask and transfer the appropriate number of cells to $1.5 \mathrm{ml}$ microcenterfuge tube and centerfuge for $5 \mathrm{~min}$ at 3000r.p.m removed the supernatant completely and resuspend cell pellet in PBS to a final volume of $200 \mu$ l. The extraction of DNA was done by 
DNeasy Blood and Tissue Kit (QIAGEN) mini (50):51304,according to manufacturer's protocols . The primers target was used in this study the repetitive kenitoplast DNA (KDNA) mini circles (Lachaud et al.2001; Marfurt et al.2003 Bensoussan et al.2006 and Delik et al.2009) which is specific for L.infantum.

The KDNA using the primers 13A (5-GTG GGG GAG GGG CGT TCT-3) forward and 13B(5-ATT TTC CAC CAA CCC CCA GTT-3), which produce a120-bp Fragment upon amplification. Thermal cycler using the following conditions: first cycle at $94^{\circ} \mathrm{C}$ for 5 min followed by 40 cycle at $94^{\circ} \mathrm{C}$ for 1 $\min , 45^{\circ} \mathrm{C}$ for $1 \mathrm{~min}$, and $72^{\circ} \mathrm{C}$ for $1 \mathrm{~min}$ and $30 \mathrm{~s}$, with the final extension cycle at $72^{\circ} \mathrm{C}$ for $10 \mathrm{~min}$ (

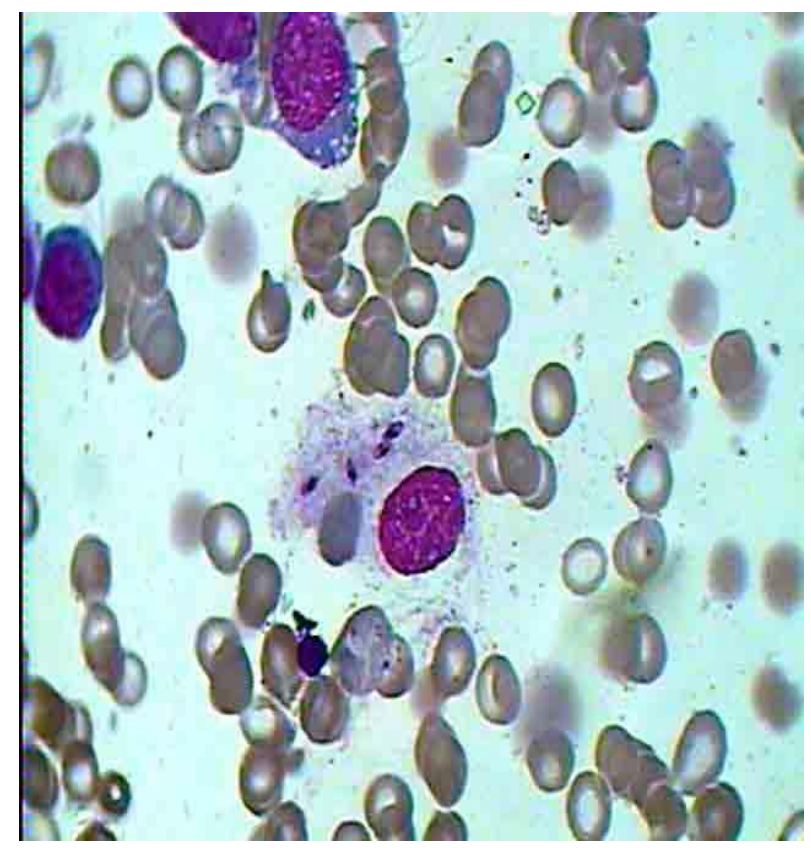

Delik et al.2009,Motazedian et al 2002 ). PCR products were analyzed on $2 \%$ agarose gel of by electrophoresis at $100 \mathrm{~V}$ in $1 \mathrm{x}$ Tris-Boric-EDTA buffer (0.04 M Tris-boric and 1mM EDTA pH 8. 0 ) and visualized by ultraviolet light and gel documentation after being stained with ethidium bromide.

\section{$\underline{\text { Results and Discussion }}$}

The results of 50 B.M slides examined with oil X100 objective were showed that 45 of them (90\%) positive, and the other five ; $5(10 \%)$ were negative as shown in Fig.(1).

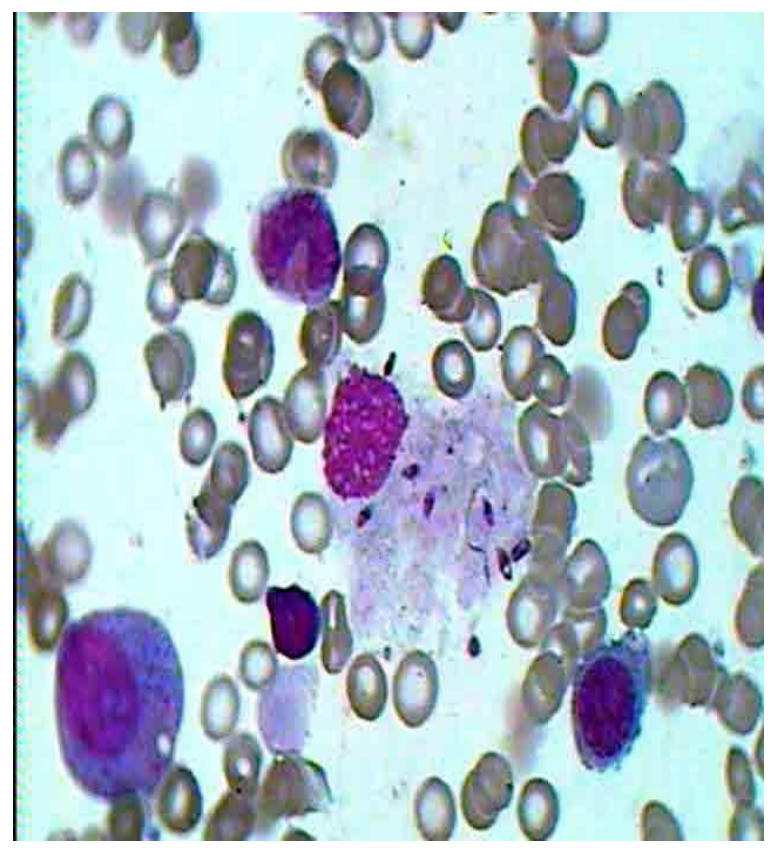

Fig.(1): positive bone marrow smears show the L.infantum bodies (amastigote) inside the macrophage by 100X oil emersion objective.

kDNA minicircles gene for 50 patients and 25 healthy control were amplified by PCR techniques using (K13A-K13B) primers . The result showed that $42(84 \%)$ were positive and $8(16 \%)$ were negative and all the healthy control patients were negative as shown in Fig (2). 

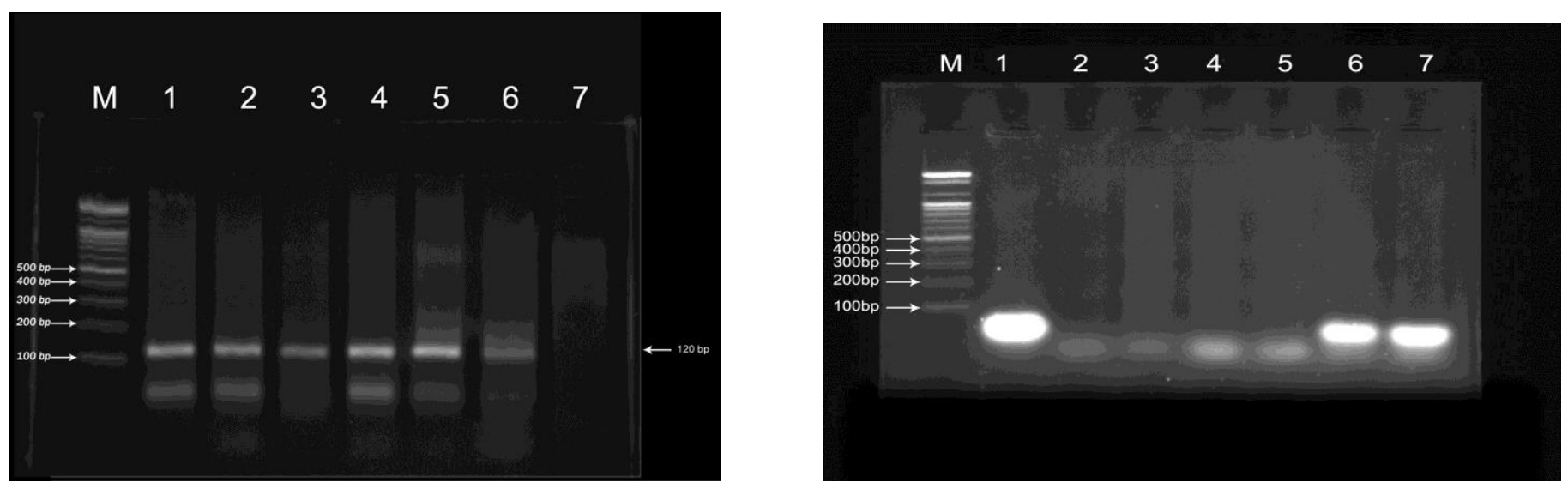

A

B

Fig.(2) A: agarose gel electrophoresis (2\%) shows (kDNA) minicircles gene amplification.

Lane $\mathrm{M}=$ Marker $100 \mathrm{bp}$.

Lane1-5= positive Patients sample.

Lane $6=$ positive control.

Lane7 =negative control (distilled water instated of DNA).

Fig.(2):B: agarose gel electrophoresis (2\%) shows negative healthy control sample.

The result of four two used in this study shows different in sensitivity and also in percent of Positive and negative patients, and statically a significant different between them (Table 1). Positive predictive value of microscopic examination were $45(90 \%)$ and (10\%) negative for visceral leishmaniasis and for PCR 42(84\%) positive , $8(16 \%)$ negative, the sensitivity and specificity for PCR $91 \%$ and $100 \%$ respectively ,with statistically significant different $(\mathrm{p}<0.001)$.

Table 1. The Results of two tests used in diagnosis of visceral leishmaniasis

\begin{tabular}{|l|c|c|c|c|c|c|c|c|}
\hline \multicolumn{1}{|c|}{ Test } & $\begin{array}{c}\text { Patient } \\
\text { positive }\end{array}$ & $\boldsymbol{\%}$ & $\begin{array}{c}\text { Patient } \\
\text { negative }\end{array}$ & $\boldsymbol{\%}$ & Sensitivity & Specificity & $\boldsymbol{\chi 2}$ & $\mathbf{t}$ \\
\hline B.M & 45 & 90 & 3 & 10 & $100 \%$ & $100 \%$ & 72.28 & 10.660 \\
\hline kDNA & 42 & 84 & 8 & 16 & $93.3 \%$ & $100 \%$ & 23.12 & 16.039 \\
\hline
\end{tabular}

For a long time, it was believed that parasites were absent or were very rare in the blood of patients with VL (Lachaud et al. 2000). Recently, molecular biology techniques were adapted for the detection of Leishmania DNA in peripheral blood (Adhya et al. 1995, Schaefer et al. 1995). (PCR) is capable of detecting these low numbers of parasites (Sundar and Rai 2002).To the best of our knowledgment this study is the first one in Iraq. Several molecular targets for a diagnostic PCR have been identified in Leishmania including minicircle kinetoplast DNA (kDNA), the miniexon (spliced leader RNA) gene, ribosomal DNA, and the glucose-6-phosphate dehydrogenase gene (Srivastava et al.,2011b). Kinetoplast DNA represents an ideal PCR target since minicircles are present at very high copy numbers $(10,000$ per parasite) and contain both conserved and variable regions that allow differentiation between Leishmania Species (Castilho et al., 2003). The present results of 50 DNA blood sample of patients with KDNA gene-specific primer were 42 (84\%) positive and 8 (16\%) negative with $91.5 \%$ sensitivity and $100 \%$ specificity with high statically significant. All the 25 DNA blood samples of healthy controls were negative. The sensitivity of PCR was reported from $82 \%$ to $100 \%$ when were compared with microscopic examination (Pal et al., 2004). The specificity of PCR was reported between $71.7 \%$ and $100 \%$ 
(Disch et al., 2006). Laurence et al.,2002 showed the methods using kinetoplastic primer (K13AK13B) proved best detection with $100 \%$ sensitivity in symptomatic and asymptomatic carriers . Other studies in children corroborate these data as fellowed: Piarroux et al. (1994) also recorded a greater sensitivity with PCR of peripheral blood (82\%) when compared with direct microscopy $(55 \%)$ and culture $(55 \%)$ tests. Cruz et al. (2006) analyzed 25 individuals and identified positive results in $67 \%$ of the children by direct microscopy and $79 \%$ by PCR of peripheral blood. Kaouech et al. (2008) evaluated the efficacy of PCR in peripheral blood in 53 children in Tunisia and reported positive results for $100 \%$ of those tested with this method compared with $79 \%$ when direct microscopy of bone marrow aspirate was used. In this study, the high level of sensitivity of PCR in peripheral blood was demonstrated by its ability to detect parasite DNA in $84 \%$ of the samples. Other authors who evaluated the use of PCR with this kind of biological material exclusively in children reported sensitivities ranging from 79-100\% (Cascio et al. 2002, Cruz et al. 2006, Kaouech et al. 2008). There was no false positive and was 4 false negative samples in our PCR results, this may be duo to inappropriate sample collection or DNA extraction ,or due to taken antileishmanial therapy. Cascio et al.,(2002) also show that parasitemia in $\mathrm{PB}$ is usually short-lived in immunocompetent children receiving antileishmanial treatment (a median of 6days to achieve PCR negativity). Finally, patient monitoring by means of Leishmania-specific PCR in the blood can predict treatment failure in a timely manner, and thus allow prompt and appropriate therapeutic adjustments.In conclusion Molecular biology based assays for detecting parasite DNA have been high specificity and sensitivity it is developed but need more works especially in Iraq.

\section{References}

Adhya, S.; Chatterjee, M.; Hassan, Q.; Mukherjee, S. and Sen, S.( 1995). Detection of leishmania in blood of early kala-azar patients with the aid of polymerase chain reaction. Trans. R. Soc. Trop. Med. Hyg. 89:622-624.

Attar, ZJ.; Chance, ML.; el-Safi, S.;Carney, J ;Azazy, A. and El-Hadi M. (2001). Latex agglutination test for the detection of urinary antigen in visceral leishmaniasis. Acta Trop; $78: 11-6$

Bensoussan , E.; Nasereddin , A.; Jonas, F.; Schnur, LF. And Jaffe,Cl.(2006).

Comparison of PCR assay for diagnosis of cutaneous leishmaniasis. J.Clin.Microbiol. 44:1435-1439.

Cascio, A.; Calattini, S.;Colomba, C.; Scalamogna,C.; Galazzi ,M.; Pizzuto, M.; Camilli ,R.; Gramiccia, M.; Titone,L.; Corbellino, M.and Spinello, A .(2002). Polymerase chain reaction in the diagnosis and prognosis of Mediterranean visceral leishmaniasis in immunocompetent children. Pediatric .109: 27-31.

Castilho ,T.; Shaw ,MJ. and Floeter-Winter ,LM.( 2003). New PCR assay using glucose-6phosphate dehydrogenase for identification of Leishmania species. J Clin Microbiol 41: 540-546.

Claborn, D. M. ( 2010 ). The biology and control of leishmaniasis vectors. J Global Infect Dis $: 2: 127-34$.

Cruz, I.; Cañavate, C.; Rubio, JM.; Morales, MA.; Chicharro ,C.; Laguna, F.; Jiménez-Mejías, M.;Sirera, G.; Videla, S.and Alvar, J.( 2002). A nested polymerase chain reaction (LnPCR) for diagnosing and monitoring Leishmania infantum infection in patients coinfected with human immunodeficiency virus. Trans $R$ SocTrop MedHyg96: 185-189

Deborggraeve, S.; Boelaert, M.; Rijal,S.; Doncker, De.; Dujardin, J-C.; Herdewijn, P. and Buscher, P.(2008). Diagnostic accuracy of a new Leishmania PCR for clinical visceral leishmaniasis in Nepal and its role in diagnosis of disease. Trop MedIntHealth 13: 1378-1383.

Disch, J.; Caligiorne, RB.; Maciel, F.; Oliveira,MC.;Orsini, M.; Dias-Neto ,E. and Rabello, A.(2006) Single -step duplex 
kDNA-PCR for detection of leishmania denovani complex in human peripheral blood sample.Diagn Microbiol Infect Dis 56:395400

Dilek ,O.;Eroglu,F.; Genc,A. ;Demirkazik, M .and Koltas, I.S.(2009). Comparsion of microscopoic examination, rK39, and PCR for visceral leishmaniasis diagnosis in Turkey. Parasitol.Res. 106: 197-200.

Herwaldt, B. L. (1999) Leishmaniasis. Lancet 354:1191-1199.

Kaouech, E.; Kallel, K.; Toumi,NH.; Belhadi, S.; Anane, S.; Babbe,H.and Chaker,E.(2008) .Pediatric visceral leishmaniasis diagnosis in Tunisia: comparative study between optimized PCR assays and parasitological methods. Parasite 15(2): 143-150.

Lachaud ,L.; Dereure ,J.;Chabbert, E.; Reynes, J.; Mauboussin, JM. and Oziol, E.( 2000). Optimized PCR using patient blood samples for diagnosis and follow-up of visceral leishmaniasis, with special reference to AIDS patients. J Clin Microbiol38: 236-240.

Lachaud, L.; Chabbert,E.; Dubessay,p.; Reynes,J.; Lamothe,L. and Bastein,P. (2001). Comparison of various sample preparation methods of PCR diagnosis of visceral leishmaniasis using peripheral blood. J. Clin. Microbiol. 38:613-617

Laurence, L.; Marchergui,H,,S.; Chabbert E,1.; Jacques,D.; Dedet, J.P and Bastien, P.(2002)Comparison of Six PCR Methods Using Peripheral Blood for Detection of Canine Visceral Leishmaniasis. J. Clin. Microbiol. 40: 210-215,

Lawyer, PG and Perkins,PV.(2004). Leishmaniasis and trypanosomiasis. In: Eldridge BF, Edman JD, editors. Medical Entomology. Dondrecht, The Netherlands: Kluwer Academic Publishers. p. 231-98.

Marfurt,J.; Abed Nasereddin, .I; Niederwieser,1.; Jaffe,C.; Beck,H and Felger,I. (2003) Identification and Differentiation of Leishmania Species in Clinical Samples by PCR Amplification of the Miniexon Sequence and Subsequent Restriction
Fragment Length Polymorphism Analysis .j.Clin. Microbiol 4(7): 3147-3153 .

Motazedian, H.;Karamian ,M.; Noyes, HA. And Ardehali S (2002). DNA extraction and amplification of Leishmania from archived, Giemsa-stained slides, for the diagnosis of cutaneous leishmaniasis by PCR. Ann Trop Med Parasitol 96: 31-34.

Pal ,S.; Aggarwal, G.; Halder,A.; Majumdar, A,; Majumdar,HK. and Duttagupta ,S.(2004) Diagnosis of symptomatic Kala-azar by Polymerase Chain Reaction using patient's blood . Med Sci Monit 10(1):MT1-MT5.

Schaefer, KU.;Schoone ,GJ.; Gachihi, GS.; Muller ,AS.; Kager ,PA. and Meredith, SE.(1995). Visceral leishmaniasis: use of the polymerase chain reaction in an epidemiological study in Baringo district, Kenya. Trans R SocTrop MedHyg89: 492-495.

Sundar,S. and Rai.M.(2002) Laboratory Diagnosis of Visceral Leishmaniasis

Clin Diag Lab Immunol. 9(5):951-958.

Srivastava, P.; Mehrotra, S.; Tiwary, C. and ,Sundar ,S.(2011a)

Diagnosis of Indian Visceral Leishmaniasis by Nucleic Acid Detection Using PCR. PLoS ONE | www.plosone.org. Volume 6. Issue 4 . e19304

Srivastava, P.; Mehrotra, S.; Tiwary, C. and, Sundar, S.(2011b) Diagnosis of Indian Visceral Leishmaniasis by Nucleic Acid Detection Using PCR. PLOS ONE | www.plosone.org. Volume 6. Issue 4 . e19304

Wilson ,ME.( 1998). Leishmaniasis in Public Health and Preventive Medicine. $14^{\text {th }}$ ed. In: Wallace RB, Boebbelin BN, editors. New York: McGraw-Hill. p. 334-6.

World Health Organization (WHO) (1990). Control of Leishmanaia. Genevia, series 793.

World Health Organization(WHO) (1995). Bridging the gap. World Health Report. World Health Organization, Geneva, Switzerland. 